\title{
Temperature and substrate regulation of bacterial abundance, production and specific growth rate in Chesapeake Bay, USA
}

\author{
Fuh-Kwo Shiah", Hugh W. Ducklow** \\ Horn Point Environmental Laboratories-CEES, University of Maryland, PO Box 775, Cambridge, Maryland 21613, USA
}

\begin{abstract}
Effects of temperature and substrate addition (glucose, ammonium or dissolved free amino acid) on bacterial growth were studied in short-term incubations of samples from north, mid and south Chesapeake Bay and a small salt marsh creek, in 1991 and 1992. Bacterial specific growth rates were exponentially and positively correlated with incubation temperature in all seasons studied. Relationships with temperature were consistently similar across different estuarine habitats and chlorophyll concentrations ( 2 to $50 \mu \mathrm{g} \mathrm{I}^{-1}$ ) at incubation temperatures ranging from 3 to $25^{\circ} \mathrm{C}$. Within this temperature range, the average $Q_{10}$ value for bacterial specific growth rates was $2.72 \pm 0.26$. Substrate enrichment did not increase bacterial abundance, production and specific growth rate within $24 \mathrm{~h}$ when water temperature was $<7^{\circ} \mathrm{C}$. At higher temperatures $\left(>20^{\circ} \mathrm{C}\right)$, substrate enrichment effects occurred after $3 \mathrm{~h}$ incubation although the effect was not consistent across study areas. Temperature-substrate interaction experiments showed that temperature was more effective in regulating bacterial production and specific growth rate than substrate when compared on the same time scale. The substrate enrichment effect on bacterial growth appeared to be temperature dependent. High temperature dependency and the lack of substrate effect on bacterial growth at temperatures $<20^{\circ} \mathrm{C}$ suggested that estuarine bacterial growth was not limited by substrate supply but by temperature during non-summer seasons. Response of bacteria to temperature was uniform across a range of time scales. There was no evidence of adaptation to in situ temperature by bacterial assemblages in different seasons. The seasonal cycle of bacterial growth rate can largely be explained as a physiological response to the in situ temperature by a eurythermal bacterial community.
\end{abstract}

KEY WORDS: Estuarine bacteria $\cdot$ Bottom-up control $\cdot$ Microbial loop

\section{INTRODUCTION}

Estuarine bacterial abundance, production and specific growth rate are potenially regulated by many environmental factors. Many studies suggest that substrate supply can be important in regulating bacterial properties. This effect can be inferred from the positive correlation between phytoplankton biomass (and/or production) and bacterial biomass (and/or production) observed in field studies and enclosure experiments

Present addresses:

- Institute of Oceanography, National Taiwan University, Taipei, Taiwan

- Department of Chemistry, Woods Hole Oceanographic Institute, Woods Hole, Massachusetts 02543, USA
(Fuhrman \& Azam 1980, Bird \& Kalff 1984, Lancelot \& Billen 1984, Bjørnsen et al. 1988, Cole et al. 1988, Currie 1990, White et al. 1991, Simon et al. 1992). However, direct evidence for this hypothesis is rarely available since the substrate stock and supply rate for bacteria is very difficult to measure directly. Ducklow \& Carlson (1992) suggested that the bottom-up control hypothesis is more difficult to prove in coastal and estuarine areas where allochthonous substrate supplies, such as terrestrial runoff and benthic fluxes, may also support bacteria. Weak, or even nonsignificant correlations between bacterial biomass (and/or production) and phytoplankton biomass (and/or production) have been observed in estuarine and coastal areas (Painchaud \& Therriault 1989, Findlay et al. 1991, Malone et al. 1991, Hoch \& Kirchman 1993). 
These studies suggest that substrate supplies from sources other than phytoplankton can sometimes support bacterial growth.

Of the physical factors, temperature has often been demonstrated to be one of the major factors correlated with the seasonal variability of bacterial abundance, production and specific growth rate in estuarine, coastal and freshwater ecosystems (White et al. 1991, Shiah 1993). However, the ecological significance of these relationships have seldom been emphasized or explicitly addressed. Intuitively, we would expect temperature to have a direct effect on the rate of numerous physiological processes of bacteria. Laboratory experiments show that when substrate supply for bacteria is not limiting, bacterial specific growth rate, the half saturation constant for substrate and bacterial growth yield vary exponentially with temperature (Schaechter et al. 1958, Topiwald \& Sinclair 1971).

Bott (1975) first hypothesized that the growth rate of bacteria in streams was not limited by substrate availability but by temperature. Lovell \& Konopka (1985) suggested that bacterial growth in lakes was limited by temperature. Hoch \& Kirchman (1993) showed that, in the Delaware estuary (Delaware, USA), bacterial specific growth rate was positively correlated with temperature $<12^{\circ} \mathrm{C}$. Ducklow \& Shiah (1993) hypothesized that the growth of bacteria in the mid Chesapeake Bay (and perhaps other estuarine habitats) was probably seldom limited by in situ substrate supply but by temperature. Shiah (1993) showed that the spatial and temporal distribution patterns in bacterial abundance, production and specific growth rate in Chesapeake Bay and a salt marsh tidal creek were strongly controlled by temperature. They concluded that the growth of bacteria during non-summer seasons $\left(<20^{\circ} \mathrm{C}\right)$ was limited by temperature rather than sub. strate supply.

By examining various data for biological temperature response of phytoplankton, zooplankton and fishes and combining Arrhenius temperature law and MichaelisMenton rate law, Quinlan (1981) demonstrated that in these 3 trophic levels, the optimum temperature at which a thermal rate maximum occurred was a function of resource level. This function constituted a thermo-chemical constraint between in situ temperature and resource availability that must be satisfied to optimize performance. Her idea is similar to hypotheses proposed later by Pomeroy et al. (1991), White et al. (1991), Wiebe et al. $(1992,1993)$ and Kirchman et al. (1993), suggesting that temperature and substrate supply affect bacteria interactively.
To provide experimental and mechanistic support for our field observations and to determine the relative importance of temperature and substrate availability in regulating bacterial growth rate, we performed shortterm temperature manipulation and substrate enrichment experiments. We reasoned that if the growth of estuarine bacteria were limited by substrate supply, then bacterial biomass, production and specific growth rate would increase after the addition of substrate and there would be no consistent relationship between temperature and bacterial properties. Our results suggest temperature is the most important factor regulating bacterial activity in Chesapeake Bay, and that the temperature effect is independent of the season, in situ temperature, habitat and chlorophyll concentration.

\section{MATERIALS AND METHODS}

Temperature manipulation experiments. Surface water samples from stations in the north, mid and south Chesapeake Bay (Fig. 1) were collected by Niskin bottles in October and November 1991 and February, May, June and August 1992. Experiments were performed immediately after the water was drawn from the Niskin bottles. Salt marsh tidal creek (Fig. 1) water samples were collected at low tide in June and October 1991 and January, February, May, June and August 1992. Water samples $(50 \mathrm{ml})$ were pre-incubated at $5,10,15,20,25,30^{\circ} \mathrm{C}$ and in situ temperature in opaque polycarbonate bottles for $1 \mathrm{~h}$, which was sufficient to allow adjustment to the new temperature. After pre-incubation, bacterial abun-

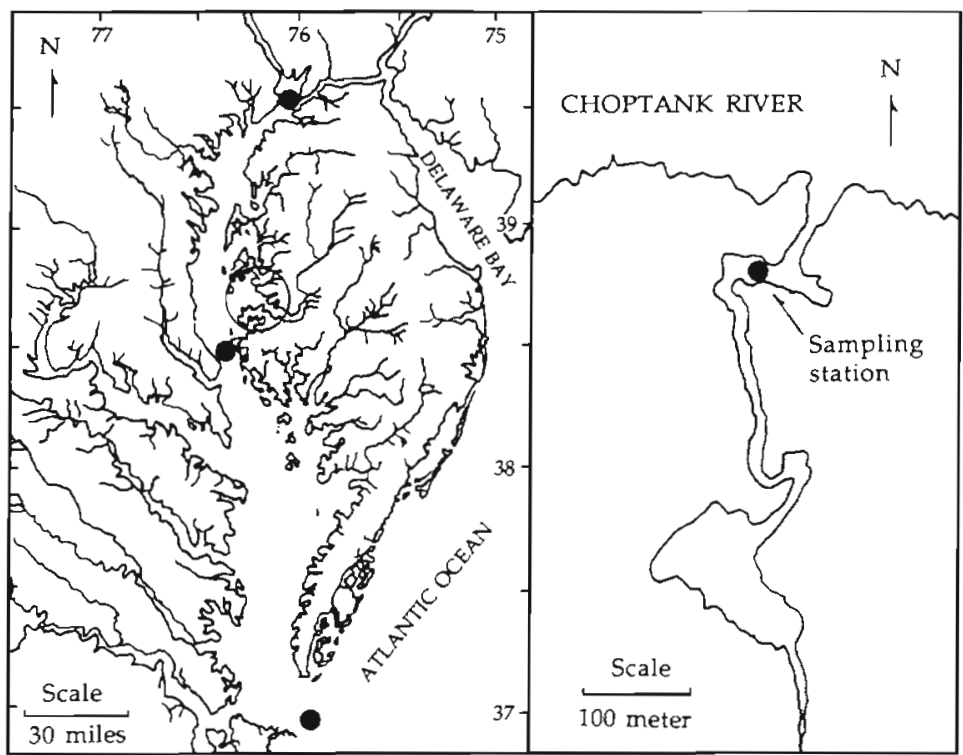

Fig. 1. Map of Chesapeake Bay area showing sampling stations 
dance and production were assayed. Temperature for each treatment was controlled within $\pm 1^{\circ} \mathrm{C}$.

Substrate enrichment experiments. Experiments were performed in the north, mid and south Chesapeake Bay and the salt marsh tidal creek in March, June and September 1992. To remove bacteriovores and reduce the possibility of organic matter release from other organisms due to cell damage, freshly collected surface water samples were filtered through $0.8 \mu \mathrm{m}$ cellulose acetate filters by gravity filtration into a $20 \mathrm{l}$ polycarbonate bottle. After mixing, the filtrate was assigned to 4 treatments which were incubated in 1 l opaque polycarbonate bottles at in situ temperature. Treatments included: (1) untreated filtrate, control; (2) glucose addition; (3) glucose plus ammonium $\left(\mathrm{NH}_{4}{ }^{+}\right)$addition; and (4) dissolved free amino acid (DFAA) addition. The final concentration of glucose, $\mathrm{NH}_{4}{ }^{+}$and DFAA was 600,10 and $75 \mu \mathrm{M}$ respectively. These concentrations were at least 2 times higher than in situ concentrations which have been reported in Chesapeake Bay (Coffin 1989, Shiah 1993, J. D. Hagy \& T. R. Fisher unpubl.). The DFAA mixture contained $5 \mu \mathrm{M}$ each of leucine, glycine, phenylalanine, arginine, proline, threonine, alanine, histidine, tyrosine, serine, isoleucine, valine, asparagine, lysine and methionine. DFAA addition was not performed in the September experiment. Bacterial abundance and ${ }^{3} \mathrm{H}$-thymidine incorporation were measured every 3 to $8 \mathrm{~h}$ for $24 \mathrm{~h}$. Substrates were added after bacterial abundance and ${ }^{3} \mathrm{H}$-thymidine incorporation were measured at the first sampling point. All equipment including filtration cartridge, filters and polycarbonate bottles were acid $(10 \% \mathrm{HCL})$ washed and rinsed with deionized water at least 3 times before experiments started. Preliminary experiments showed that the addition of glucose, $\mathrm{NH}_{4}{ }^{+}$, DFAA and $\mathrm{PO}_{4}{ }^{-3}$ (final concentration: 100, 10,75 and $5 \mu \mathrm{M}$ respectively) did not enhance ${ }^{3} \mathrm{H}$-thymidine incorporation prior to 3 to $5 \mathrm{~h}$. The specific growth rates in $0.8 \mu \mathrm{m}$ filtrates were close to those in the whole water samples (Shiah 1993).

Temperature-substrate interaction experiments. To test the interaction between temperature and substrate addition, at the last sampling point of the March 1992 tidal creek experiment and the June 1992 mid Bay experiment (i.e. 24 to $30 \mathrm{~h}$ after substrate addition), the whole water sample, control and treatments were split and incubated at in situ temperatures and also at higher temperatures $\left(19^{\circ} \mathrm{C}\right.$ for the March experiment and $28^{\circ} \mathrm{C}$ for the June experiment) for 1 additional hour before measuring ${ }^{3} \mathrm{H}$-thymidine incorporation.

Bacterial abundance. Bacterial abundance was determined by the acridine orange direct count method (Hobbie et al. 1977). Samples fixed with glutaraldehyde (final concentration $1 \%$ ) were stained with acridine orange (final concentration $0.01 \%$ ) for
2 min and then filtered through $0.2 \mu \mathrm{m}$ polycarbonate filters prestained with Irgalan black solution. Filters mounted in Cargille Type A immersion oil on slides were enumerated at $1650 \times$ by epifluorescence microscopy (ZEISS, Axiphot) with a $100 \mathrm{~W}$ mercury lamp, blue BP 450-490 exciter filter and LP520 barrier filter

Bacterial production and specific growth rate. Bacterial production was estimated by ${ }^{3} \mathrm{H}$-thymidine (Fuhrman \& Azam 1980, 1982) and ${ }^{3} \mathrm{H}$-leucine (Kirchman et al. 1985, Chin-Leo \& Kirchman 1988) incorporation separately. Duplicate or triplicate $10 \mathrm{ml}$ aliquots of freshly collected water were incubated with ${ }^{3} \mathrm{H}$-[methyl]-thymidine (specific activity 20 to $85 \mathrm{Ci}$ $\mathrm{mmol}^{-1}$, final concentration $10 \mathrm{nM}$ ) in opaque polycarbonate bottles at in situ temperature for $0.5 \mathrm{~h}$. Preliminary tests showed that this concentration saturated thymidine uptake systems of natural bacteria from the sampling areas. Incorporation was stopped by adding formaldehyde (final concentration 1\%). Killed samples, including the time zero control, were filtered through $0.2 \mu \mathrm{m}$ polycarbonate filters, rinsed 4 times with ice cold $5 \%$ TCA and then 4 times with $80 \%$ ethyl alcohol. Scintillation cocktail $(10 \mathrm{ml}$; Formula 963 , Dupont) was added after filters had been dried at $35^{\circ} \mathrm{C}$ overnight in their vials. Radioactivity was counted by liquid scintillation (Packard, 2200CA). Water samples also were incubated with $\mathrm{L}-\left[3,4,5-{ }^{3} \mathrm{H}\right.$-(N)]-leucine (final concentration $22 \mathrm{nM}$; $1 \mathrm{nM}$ labeled leucine and 21 nM unlabeled leucine). The extraction procedures were the same as those for cold TCA thymidine incorporation. Thymidine and leucine incorporation rates normalized by bacterial abundance were used as an index for bacterial specific growth rate.

Data analysis. Statistical analysis including analysis of variance (ANOVA), analysis of covariance (ANCOVA), linear regression (Model I) and the Komogorov-Smirnov test were performed using SYSTAT (Wilkinson et al. 1992). To equalize the variance, bacterial abundance, thymidine incorporation rate and specific growth rate were natural-log transformed in regression and ANCOVA analysis (Edwards 1985). Normality of transformed data was tested by the Komogorov-Smirnov test.

\section{RESULTS}

Table 1 lists the ranges of all measured variables at the 4 study areas when experiments were performed. in situ bacterial abundance, thymidine incorporation rate and leucine incorporation rate ranged from 2.1 to $17.1 \times 10^{9}$ cells $\mathrm{l}^{-1}, 6$ to $720 \mathrm{pM} \mathrm{h}^{-1}$ and 30 to $4800 \mathrm{pM}$ $\mathrm{h}^{-1}$ respectively. They were within the annual range of field data of 1990 and 1991 reported by Shiah (1993) 
Table 1. Ranges of all measured variables for temperature manipulation and substrate enrichment experiments performed in different study areas. Numbers in parentheses indicate sample size

\begin{tabular}{|lcccccr|}
\hline Area & $\begin{array}{c}\text { Temperature } \\
\left({ }^{\circ} \mathrm{C}\right)\end{array}$ & $\begin{array}{c}\text { Bacterial } \\
\text { abundance } \\
\left(10^{9} \mathrm{cells} \mathrm{I}^{-1}\right)\end{array}$ & $\begin{array}{c}\text { Thymidine } \\
\text { incorp. rate } \\
\left(\mathrm{pM} \mathrm{h}^{-1}\right)\end{array}$ & $\begin{array}{c}\text { Leucine } \\
\text { incorp. rate } \\
\left(\mathrm{pM} \mathrm{h}^{-1}\right)\end{array}$ & $\begin{array}{c}\text { Chlorophyll } \\
\left(\mu \mathrm{I}^{-1}\right)\end{array}$ & $\begin{array}{c}\text { Ammonium } \\
(\mu \mathrm{M})\end{array}$ \\
\hline Tidal creek & $3-32(6)$ & $3.0-17.1(6)$ & $6-720(6)$ & $120-4800(5)$ & $2.4-17.7(6)$ & $1.99-9.24(6)$ \\
North Bay & $3-24(5)$ & $2.2-6.8(5)$ & $7-80(5)$ & $36-355(5)$ & $1.8-16.9(5)$ & $1.98-8.71(5)$ \\
Mid Bay & $4-25(7)$ & $2.7-11.3(7)$ & $9-140(7)$ & $32-1100(6)$ & $2.3-51.0(7)$ & $0.18-1.91(7)$ \\
South Bay & $5-25(5)$ & $2.1-10.1(5)$ & $6-105(5)$ & $30-1250(5)$ & $1.7-8.3(5)$ & $0.04-2.72(5)$ \\
\hline
\end{tabular}

and were all positively correlated with temperature (n $=32, \mathrm{p}<0.01)$.

\section{Temperature manipulation experiments}

The specific rate of ${ }^{3} \mathrm{H}$-thymidine incorporation $(\mathrm{TdR}$ cell $^{-1}$ ), an index of the specific growth rate of the cells, was positively correlated with incubation temperature

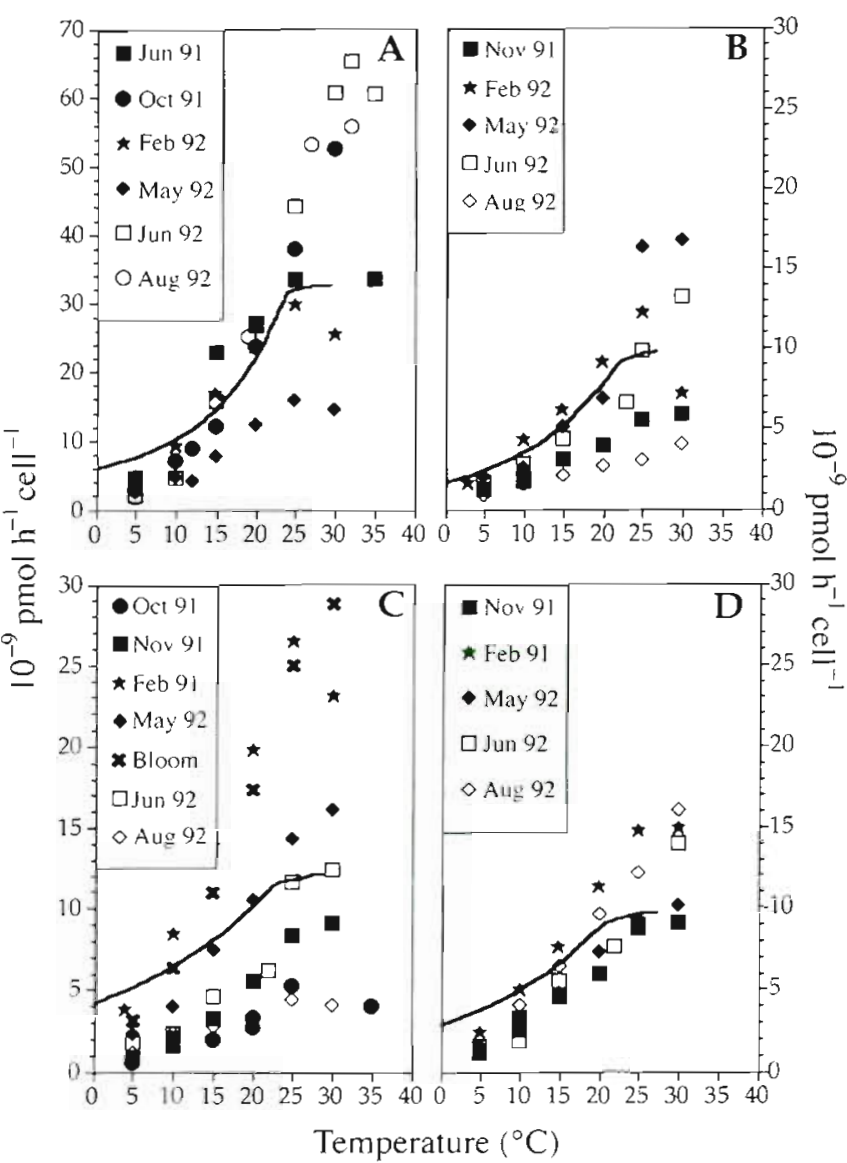

Fig. 2. Thymidine incorporation rate per cell versus temperature for manipulation experiments. (A) Tidal creek; (B) north Bay; (C) mid Bay; (D) south Bay. Note $y$-scales differ among graphs. Solid lines indicated in situ specific growth rates derived from the field studies performed in each area (Shiah 1993)
(Fig. 2A to D). In most experiments, irrespective of the in situ temperature, TdR cell ${ }^{-1}$ increased up to $25^{\circ} \mathrm{C}$, occasionally to $30^{\circ} \mathrm{C}$. Only samples from the coldest in situ temperatures (February 1992, 3 to $5^{\circ} \mathrm{C}$ ) declined between 25 and $30^{\circ} \mathrm{C}$. For many of the experiments in the tidal creek, north and south Bay, the temperatureactivity curves were very similar in the temperature range 5 to $20^{\circ} \mathrm{C}$. That is, at a given incubation temperature, the resulting values for $\mathrm{TdR} \mathrm{cell}^{-1}$ were similar to each other and to the observed in situ value for TdR cell $^{-1}$ at that temperature. For example, in the tidal creek experiments, samples from the October 1991.

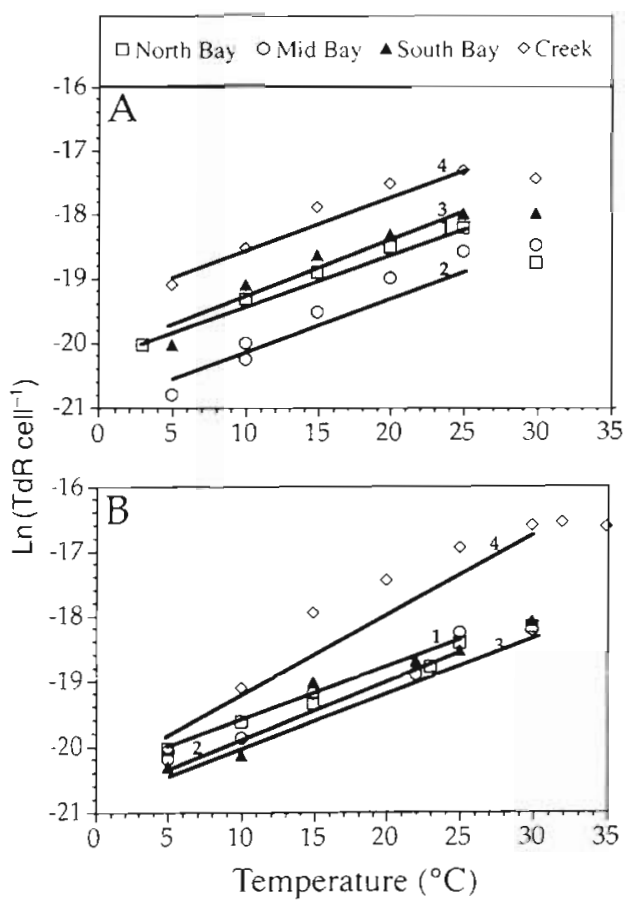

Fig. 3. Thymidine incorporation rate per cell (natural-log transformed) versus temperature for the (A) February 1992 and (B) June 1992 temperature manipulation experiments. Line of best fit for each experiment was plotted. 1, 2, 3 and 4 indicate the north Bay, mid Bay, south Bay and tidal creek experiments respectively. The symbols show the mean of triplicate determinations at each temperature. All coefficients of variation for the means were $<5 \%$ 
Table 2. Slopes for linear regression of natural-log transformed thymidine incorporation rate per cell and leucine incorporation rate per cell on temperature for 23 temperature manipulation experiments. All slopes were significant at $p<0.05$. Data from 5 to $25^{\circ} \mathrm{C}$ were used for regressions with exceptions indicated by ${ }^{\mathrm{a}}\left(5\right.$ to $\left.30^{\circ} \mathrm{C}\right)$ and ${ }^{\mathrm{b}}\left(3\right.$ to $\left.35^{\circ} \mathrm{C}\right)$. Underlined values indicate maximum and minimum slope values. NA: not available; SE: standard error

\begin{tabular}{|c|c|c|c|c|c|}
\hline Areas & Expt no. & $\begin{array}{l}\text { In situ temp- } \\
\text { erature }\left({ }^{\circ} \mathrm{C}\right)\end{array}$ & Date & $\begin{array}{l}\text { Slope ( } \pm \text { SE) for thymidine } \\
\text { incorp cell }{ }^{-1}\end{array}$ & $\begin{array}{l}\text { Slope ( } \pm S E \text { ) for leucine } \\
\text { incorp. cell }{ }^{-1}\end{array}$ \\
\hline Tidal creek & $\begin{array}{l}1 \\
2 \\
3 \\
4 \\
5 \\
6\end{array}$ & $\begin{array}{r}12 \\
20 \\
5 \\
12 \\
32 \\
32\end{array}$ & $\begin{array}{l}\text { Jun } 1991 \\
\text { Oct } 1991 \\
\text { Feb } 1992 \\
\text { May } 1992 \\
\text { Jun } 1992 \\
\text { Aug } 1992\end{array}$ & $\begin{array}{l}0.10 \pm 0.01 \\
0.11 \pm 0.01^{d} \\
0.09 \pm 0.01 \\
0.09 \pm 0.01 \\
0.12 \pm 0.02^{\mathrm{a}} \\
\underline{0.13 \pm 0.02}\end{array}$ & $\begin{array}{c}0.13 \pm 0.01^{\mathrm{b}} \\
0.14 \pm 0.01 \\
0.09 \pm 0.01 \\
0.13 \pm 0.01 \\
0.16 \pm 0.01^{\mathrm{d}} \\
\mathrm{NA}\end{array}$ \\
\hline North Bay & $\begin{array}{r}7 \\
8 \\
9 \\
10 \\
11\end{array}$ & $\begin{array}{r}10 \\
3 \\
15 \\
23 \\
25\end{array}$ & $\begin{array}{l}\text { Nov } 1991 \\
\text { Feb } 1992 \\
\text { May } 1992 \\
\text { Jun } 1992 \\
\text { Aug } 1992\end{array}$ & $\begin{array}{l}0.08 \pm 0.01 \\
0.09 \pm 0.01 \\
0.10 \pm 0.01 \\
0.08 \pm 0.01 \\
0.06 \pm 0.01\end{array}$ & $\begin{array}{l}0.10 \pm 0.01 \\
0.17 \pm 0.02 \\
0.12 \pm 0.01 \\
0.13 \pm 0.01^{\mathrm{a}} \\
0.11 \pm 0.01\end{array}$ \\
\hline Mid Bay & $\begin{array}{l}12 \\
13 \\
14 \\
15 \\
16 \\
17\end{array}$ & $\begin{array}{r}20 \\
10 \\
4 \\
15 \\
22 \\
25\end{array}$ & $\begin{array}{l}\text { Oct } 1991 \\
\text { Nov } 1991 \\
\text { Feb } 1992 \\
\text { May } 1992 \\
\text { Jun } 1992 \\
\text { Aug } 1992\end{array}$ & $\begin{array}{l}0.10 \pm 0.01 \\
0.11 \pm 0.01 \\
0.09 \pm 0.01 \\
0.10 \pm 0.01 \\
0.10 \pm 0.01 \\
0.09 \pm 0.01\end{array}$ & $\begin{array}{l}0.15 \pm 0.01 \\
0.12 \pm 0.01^{\mathrm{a}} \\
0.15 \pm 0.01 \\
0.11 \pm 0.01^{\mathrm{a}} \\
0.15 \pm 0.01^{\mathrm{a}} \\
0.17 \pm 0.02\end{array}$ \\
\hline South Bay & $\begin{array}{l}18 \\
19 \\
20 \\
21 \\
22\end{array}$ & $\begin{array}{r}10 \\
5 \\
15 \\
21 \\
25\end{array}$ & $\begin{array}{l}\text { Nov } 1991 \\
\text { Feb } 1992 \\
\text { May } 1992 \\
\text { Jun } 1992 \\
\text { Aug } 1992\end{array}$ & $\begin{array}{l}0.10 \pm 0.01 \\
0.09 \pm 0.01 \\
0.09 \pm 0.01 \\
0.09 \pm 0.01^{\mathrm{a}} \\
0.05 \pm 0.01\end{array}$ & $\begin{array}{l}0.14 \pm 0.01 \\
0.10 \pm 0.01 \\
0.14 \pm 0.01 \\
0.15 \pm 0.01^{\mathrm{a}} \\
0.14 \pm 0.01\end{array}$ \\
\hline Bloom & 23 & 15 & May 1992 & $0.10 \pm 0.01$ & NA \\
\hline Average & & & & 0.1 & 0.13 \\
\hline
\end{tabular}

February, June and August 1992 experiments, the TdR cell ${ }^{-1}$ values were $23.8,23.7,26.7$ and $25.1 \times 10^{-9} \mathrm{pmol}$ cell $^{-1} \mathrm{~h}^{-1}$ (Fig. 2A), close to the observed in situ value of $24.0 \times 10^{-9} \mathrm{pmol} \mathrm{cell}^{-1} \mathrm{~h}^{-1}$ (Shiah 1993). Above $20^{\circ} \mathrm{C}$, the range of resulting $\mathrm{TdR}$ cell $^{-1}$ values at the manipulated temperatures diverged, and in the midBay experiments, the variability in $\mathrm{TdR}$ cell $^{-1}$ at a given temperature was greater over the whole range of incubation temperature.

In spite of the variability, however, the response of the cell populations was very consistent and independent of sampling date, in situ temperature and location (Fig. 3A, B, Table 2). That is, regressions of $\ln (\mathrm{TdR}$ cell $\left.^{-1}\right)$ and $\ln \left(\right.$ Leu cell $\left.{ }^{-1}\right)$ on temperature for each experiment had very similar slopes. Fig. 3A, B shows examples for February and June 1992. The slopes for all experiments were similar, within and between habitats and dates (Table 2). In 1 experiment (Expt 6), the slope for $\ln \left(\mathrm{TdR}\right.$ cell ${ }^{-1}$ ) was significantly higher and for 2 others (Expts 11 \& 22) significantly lower than those of the other experiments. Additionally, in Expt 3, the slope for $\ln \left(\right.$ Leu cell ${ }^{-1}$ ) was significantly lower and for Expts 8 \& 17 significantly higher than those of the other experiments (ANCOVA, $\mathrm{p}<0.05)$. Overall, the slopes for $\ln \left(\mathrm{TdR}_{\mathrm{Cell}}{ }^{-1}\right)$ and In (Leu cell $\left.{ }^{-1}\right)$ were very consistent, with average values of 0.10 and 0.13 respectively. These response coefficients (i.e. slopes) were similar across a range of in situ chlorophyll concentrations of 2 to $50 \mu \mathrm{g} \mathrm{l}^{-1}$ (Fig. 4A, B). Specific growth rate was strongly regulated by temperature in a consistent way in all areas of Chesapeake Bay at all times of the year.

\section{Substrate enrichment and temperature-substrate interaction experiments}

Overall, substrate addition did not have as strong an effect on bacterial properties as temperature. In March, when water temperature was $<7^{\circ} \mathrm{C}$, substrate addition did not increase bacterial abundance, ${ }^{3} \mathrm{H}$ thymidine incorporation, or TdR cell ${ }^{-1}$ over $24 \mathrm{~h}$ in any of the experimental treatments, for any area except the north Bay (Fig. 5a to l). There, thymidine incorporation was elevated by about $33 \%$ over the control after $24 \mathrm{~h}$ (Fig. 5e). All the treatments responded equally to an increase in the incubation temperature from 5 to $19^{\circ} \mathrm{C}$ after $24 \mathrm{~h}$ (Fig. 6). 


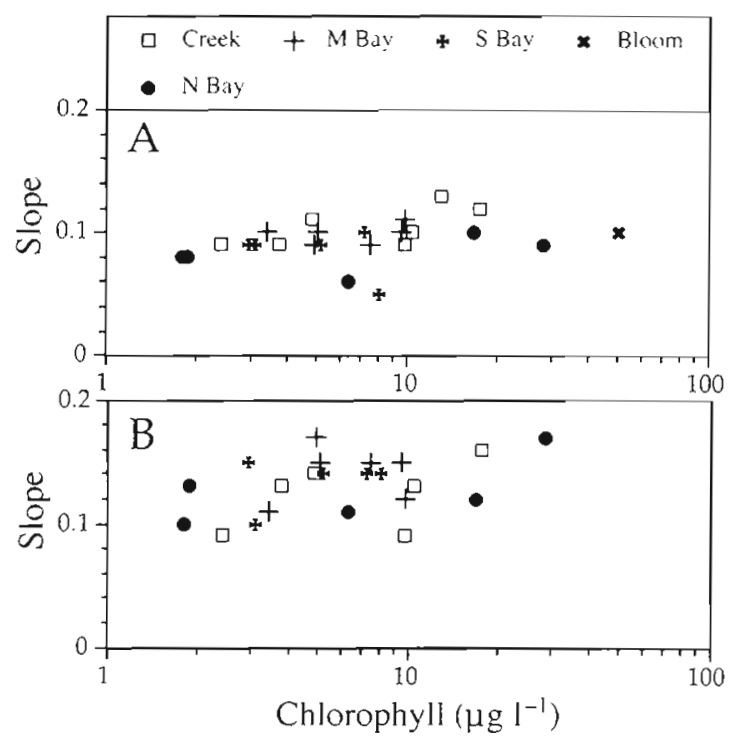

Fig. 4. Slopes for regressions of temperature on (A) ln (thymidine incorporation rate cell ${ }^{-1}$ ) and (B) $\ln$ (leucine incorporation rate cell ${ }^{-1}$ ) plotted against in situ chlorophyll concentrations (in $\log _{10}$ scale) in the experimental samples. Data from Tables $1 \& 2$

In June, when water temperature exceeded $20^{\circ} \mathrm{C}$, substrate addition affected bacterial abundance and ${ }^{3} \mathrm{H}$-thymidine incorporation. However, the patterns were not consistent. In the tidal creek, bacterial abundance, ${ }^{3} \mathrm{H}$-thymidine incorporation and $\mathrm{TdR}$ cell-1 of the substrate treatments were higher than those of the

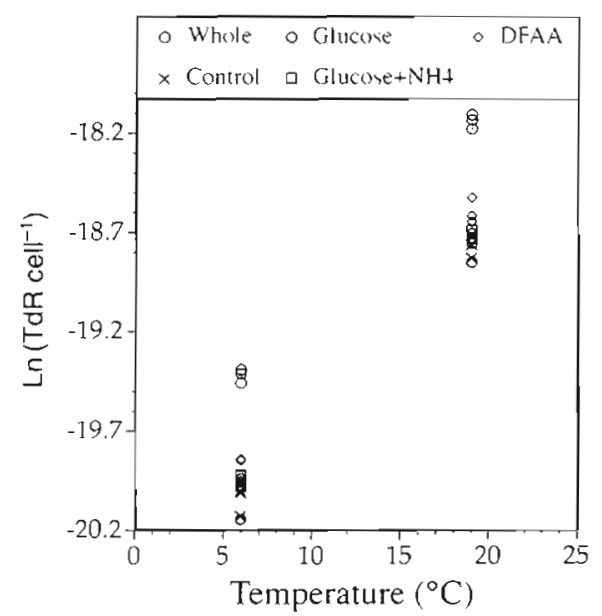

Fig. 6. Temperature versus thymidine incorporation rate cell-1 (natural-log transformed) for the March 1992 tidal creek substrate enrichment experiment. Temperatures were adjusted $24 \mathrm{~h}$ after substrate addition. Three replicates for each treatment

controls after 2 to $5 \mathrm{~h}$ incubation, with DFAA treatment having the strongest effect. (Figs. $7 \mathrm{a}$ to c). Substrate addition had no effect on bacterial abundance in north, mid and south Bay samples (Fig. 7d, g, j). ${ }^{3} \mathrm{H}$-thymidine incorporation and TdR cell ${ }^{-1}$ in north and south Bay were enhanced by the substrate addition after 24 and $7 \mathrm{~h}$ incubation respectively (Fig. 7e, f, k, l). After $24 \mathrm{~h}$ incubation, the ${ }^{3} \mathrm{H}$-thymidine incorporation with glucose plus $\mathrm{NH}_{4}{ }^{+}$treatment was $18 \%$ higher than that of glucose treatment in the south Bay (Fig. $7 \mathrm{k}$;
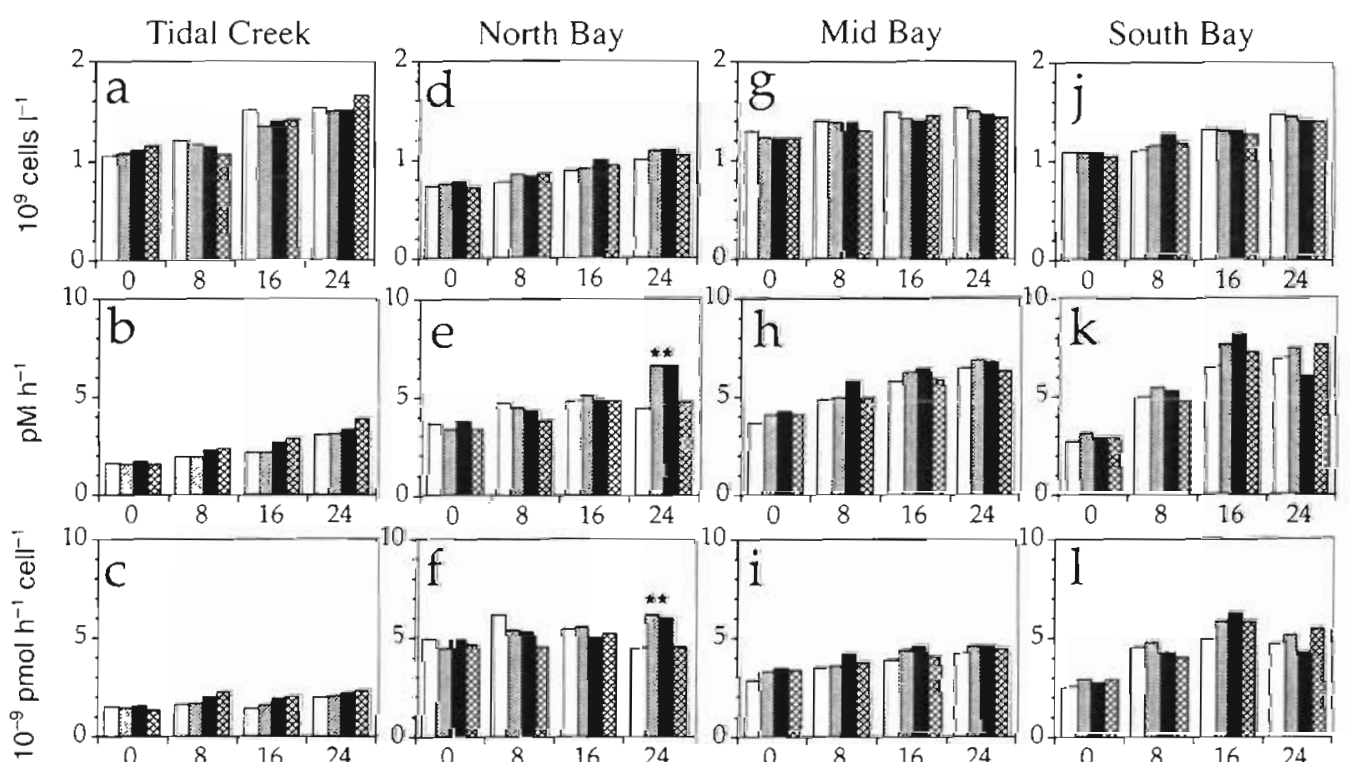

Time $(h)$
Fig. 5. Nutrient enrichment effects on bacterial abundance (upper), thymidine incorporation rate (middle), and thymidine incorporation rate cell ${ }^{-1}$ (lower) performed in March 1992. "Treatment is different from the control at $\mathrm{p}<0.05$ 


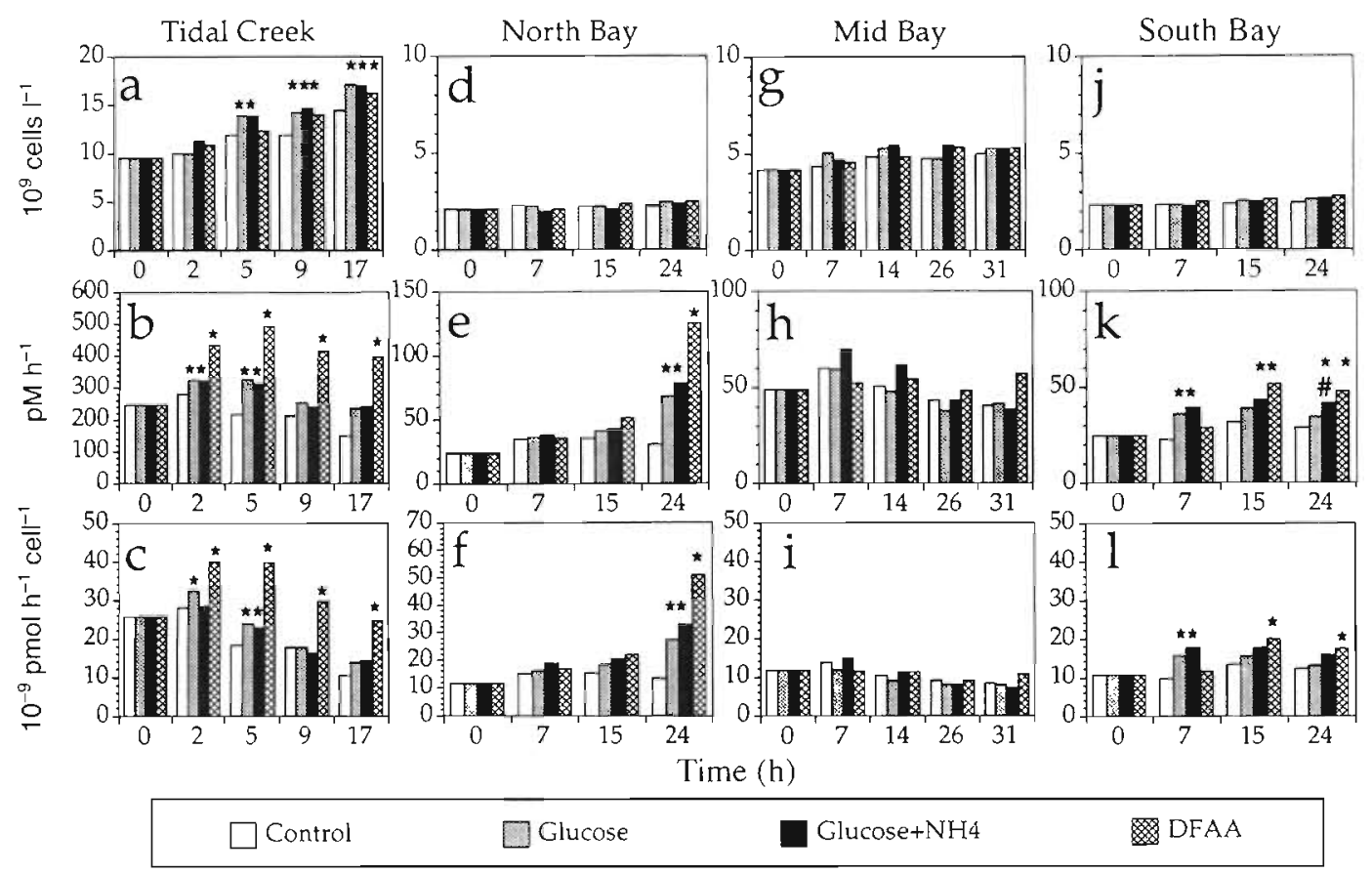

Fig. 7. Nutrient enrichment effects on bacterial abundance (upper), thymidine incorporation rate (middle), thymidine incorporation rate cell ${ }^{-1}$ (lower) performed in June 1992. "Treatment is different from the control at $\mathrm{p}<0.05$. \#: Glucose plus $\mathrm{NH}_{4}{ }^{+}$ treatment was different from glucose treatment at $p<0.05$

ANOVA, $p<0.05)$. Substrate effects on bacterial variables were not observed in mid-Bay samples.

Fig. 8 shows the results of the June 1992 temperature-substrate interaction experiment performed in the mid Bay. After increasing temperature from 22 to $28^{\circ} \mathrm{C}$, TdR cell ${ }^{-1}$ of the control and treatments all increased $75 \%$ in $1 \mathrm{~h}$ (ANOVA, p > 0.05). Note that even when substrate appeared to limit bacterial growth, temperature effects were still observed.

In September, the tidal creek experiment followed the same trends as those of the June experiment. Bacterial abundance, ${ }^{3} \mathrm{H}$-thymidine incorporation and TdR cell $^{-1}$ of the substrate treatments were higher than those of the controls after $5 \mathrm{~h}$ incubation (Fig. 9a to c). In the north Bay, substrate addition effects were not observed in $12 \mathrm{~h}$ (Fig. 9d to f). However, the glucose treatment enhanced ${ }^{3} \mathrm{H}$-thymidine incorporation and TdR cell ${ }^{-1}$ in mid and south Bay in 6 and $4 \mathrm{~h}$ respectively. (Fig. 9h, i, k, l; ANOVA, p <0.05).

\section{DISCUSSION}

\section{Temperature manipulation experiments}

In the temperature manipulation experiments, the total incubation time (i.e. 1.5 to $2 \mathrm{~h}$ ) was too short for bacterial abundance to change. These experiments addressed the effects of temperature on cell physiology (i.e. TdR cell-1, Leu cell-1). Laboratory experiments show that when grown in substrate-unlimited conditions, the rate of DNA chain extension of Escherichia coli $\mathrm{B} / \mathrm{r}$ is controlled by temperature

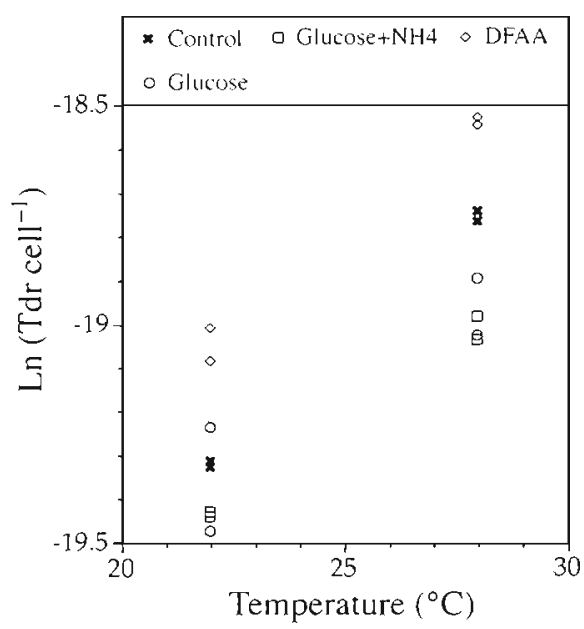

Fig. 8. Temperature versus thymidine incorporation rate cell ${ }^{-1}$ (natural-log transformed) for the June 1992 mid Chesapeake Bay substrate enrichment experiment. Temperatures were adjusted $24 \mathrm{~h}$ after substrate addition. Two replicates for each treatment 

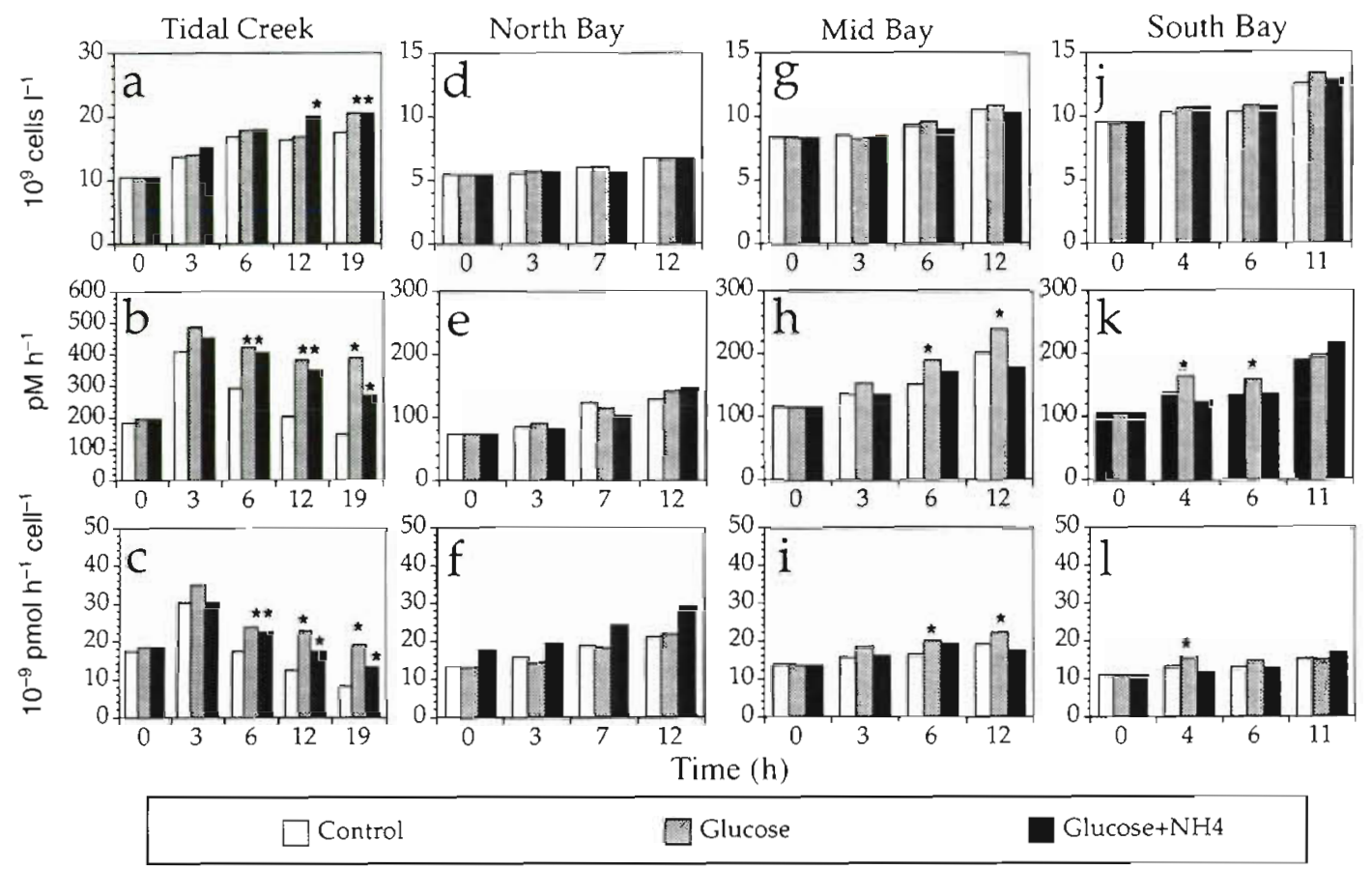

Fig. 9. Nutrient enrichment effects on bacterial abundance (upper), thymidine incorporation rate (middle), thymidine incorporation rate cell ${ }^{-1}$ (lower) performed in September 1992. "Treatment is different from the control at $p<0$.05. DFAA enrichment was not performed

(Chesbro et al. 1990 and citations therein). Higher temperatures may enhance multiple chromosome replication and, thus, the rate of cell division.

We hypothesized that bacterial specific growth rate in temperate estuaries was not limited by in situ substrate supply but by temperature during non-summer seasons (i.e. temperature $<20^{\circ} \mathrm{C}$ ). This is supported by results which showed that $\mathrm{TdR}$ cell $^{-1}$ and Leu cell ${ }^{-1}$ increased exponentially with temperature and then leveled off around 20 to $25^{\circ} \mathrm{C}$. If bacterial growth was limited by substrate, then increasing incubation temperature would be less likely to enhance $\mathrm{TdR}$ cell ${ }^{-1}$ (and Leu cell ${ }^{-1}$ ). Autio (1992) showed that in batch cultures, bacterial specific growth rate covaried with incubation temperatures up to ca $20^{\circ} \mathrm{C}$ and remained stable. Hollibaugh (1979) also showed the same phenomenon for bacterial DFAA uptake rates.

The results also indicated that in situ temperature during non-summer seasons was too low to yield maximal specific growth rates. This has been also observed by other investigations (Bott 1975, Witzel 1980, Lovell \& Konopka 1985, Servias \& Billen 1989, Upton et al. 1990, Autio 1992). Bott (1975) showed that stream bacteria were not optimally adapted to the prevailing water temperature, but rather to temperatures 5 to $20^{\circ} \mathrm{C}$ higher. He suggested that bacterial growth rates in streams were unlikely to be limited by substrate availability and that temperature had an overriding influence on growth rate. Witzel (1980) found that higher incubation temperatures enhanced bacterial metabolic rates but also reduced the substrate affinity. We suggest that when substrate supply is not limiting, bacterial growth is simply controlled by temperature and when temperatures exceed $20^{\circ} \mathrm{C}$, substrates could be exhausted by fast-growing bacteria and begin to limit bacterial growth.

Results from our warming-up and cooling-down experiments indicated that estuarine bacteria were eurythermal: they could adapt to a sudden increase or decrease of temperature without terminating their activity. There was no evidence of thermal stress and none for psychrophily in winter samples. In the tidal creek, temperature changed up to ca $10^{\circ} \mathrm{C}$ over 1 diel cycle (Shiah 1993). Physiological adaptation of bacteria to seasonal mean temperature may be less important than the ability to respond quickly to changing environmental conditions (Upton et al. 1990).

Greater variations in $\mathrm{TdR}$ cell ${ }^{-1}$ observed at higher temperatures (i.e. $>20^{\circ} \mathrm{C}$ ) revealed both short- and long-term temperature adaptation. Adaptation can be defined as an organism adapts to a given environmental condition when its response to that condition depends on the state of condition prevailing during its growth (Li \& Dickie 1987). The rate.compensation 
hypothesis has been proposed to explain the shortterm temperature adaptation of phytoplankton (Li \& Morris 1982 and citations therein). Their results showed that when incubation temperature changed from 25 to $15^{\circ} \mathrm{C}$, for example, the new specific growth rates at $15^{\circ} \mathrm{C}$ were lower (i.e. partial compensation) than the specific growth rate of the same species that had been growing at $15^{\circ} \mathrm{C}$ all the time (i.e. long-term temperature adaptation). Both partial and inverse (i.e. new specific growth rates were higher than in situ specific growth rates) compensation was observed in our study. Either genotypic or phenotypic adaptations could have occurred. Bacterial populations in the water samples taken from different seasons and different locations might be different (Lee \& Fuhrman 1990). If this is the case, then our results indicate that below $20^{\circ} \mathrm{C}$, the temperature dependency of specific growth rate for different bacterial populations is quite similar.

\section{Temperature effects over different temporal and spatial scales}

In a study performed in coastal Nova Scotia, Canada, Hollibaugh (1979) showed that the lag period (48 to $240 \mathrm{~h}$ ) required for bacteria to respond to substrate (DFAA) enrichment was negatively correlated with temperature. The slopes for the lag period on temperature were similar both at seasonal (slope, $-4.7 \mathrm{~h}$ per ${ }^{\circ} \mathrm{C}$ ) and daily (slopes, -3.9 and $-5.0 \mathrm{~h}$ per ${ }^{\circ} \mathrm{C}$ ) scales. Iriberri et al. (1985) showed that the slope $(b=0.217)$ for bacterial ${ }^{14} \mathrm{C}$-glucose uptake on temperature (12 to $22^{\circ} \mathrm{C}$ ) was very similar to the results of Maita \& Yanada $(1978 ; b=0.210)$ and Bolter $(1982 ; b=0.216)$, although these 3 studies were performed in different seasons and locations. Chin-Leo \& Benner (1992) also showed that bacterial production and abundance in winter experiments $\left(9\right.$ to $17^{\circ} \mathrm{C}$ ) from the Mississippi River plume were not enhanced by the addition of glucose, $\mathrm{NH}_{4}{ }^{+}$and $\mathrm{PO}_{4}{ }^{-3}$ within $35 \mathrm{~h}$. But in summer, when temperature exceeded $28^{\circ} \mathrm{C}$, bacterial growth near the outflow of the Mississippi River was limited by labile carbon, whereas in the plume waters of intermediate salinity (31 psu), their growth was $\mathrm{PO}_{4}^{-3}$ and $\mathrm{NH}_{4}{ }^{+}$limited. They concluded that in the winter, bacteria might be temperature limited rather than substrate limited.

The slopes for ln ( $\mathrm{TdR}$ cell $\left.{ }^{-1}\right)$ on temperature on a scale of hours were homogeneous across different areas (Table 2). They are also close to the values for daily (slope: 0.08 to 0.14 ; Shiah 1993) and seasonal (0.08 to 0.17; Shiah 1993) scales. These data suggest that the temperature dependence of bacterial specific growth rate is uniform over a range of spatial and temporal scales and that it is independent of in situ sub- strate supply rates (e.g. chlorophyll concentrations). The seasonal cycle of estuarine bacteria can be interpreted as a physiological response of the growth rate to the in situ temperature. More importantly, our results directly prove that bacterial specific growth rate in temperate estuaries during non-summer seasons is not limited by substrate supply, but by temperature. Given an averaged slope value of $0.1 \pm 0.01$ for $\ln \left(\mathrm{TdR}\right.$ cell ${ }^{-1}$ ) on temperature, the $Q_{10}$ value is $2.72 \pm 0.26$.

\section{Substrate enrichment experiments}

Bacterial abundance, ${ }^{3} \mathrm{H}$-thymidine incorporation and TdR cell ${ }^{-1}$ were enhanced by substrate addition only during warm seasons when temperature exceeded $20^{\circ} \mathrm{C}$ although the patterns were not consistent. For those cases which showed substrate effects, bacterial growth was limited by labile organic carbon and nitrogen (glucose and DFAA) except for the experiment performed in south Bay in June which suggested that $\mathrm{NH}_{4}{ }^{+}$might also limit bacterial growth. This $\mathrm{Co}-$ incided with low initial $\mathrm{NH}_{4}{ }^{+}$concentration at the beginning of experiment $(0.04 \mu \mathrm{M})$.

Recent investigations have shown that bacterial growth can be limited by the availability of inorganic phosphorus (Toolan et al. 1991, Chin-Leo \& Benner 1992, Coveney \& Wetzel 1992). For the experiments which showed no substrate (carbon and/or nitrogen) addition effect, one might suspect that it was due to the phosphorus limitation on bacterial growth. However, this is not the case for this study. Preliminary experiments showed that for both whole water and $0.8 \mu \mathrm{m}$ filtrate samples, the addition of $5 \mu \mathrm{M} \mathrm{PO}_{4}{ }^{-3}$ did not enhance ${ }^{3} \mathrm{H}$-thymidine incorporation of the mid-Bay water samples after $6 \mathrm{~h}$ incubation.

The results also suggest that substrate effects on bacterial abundance, ${ }^{3} \mathrm{H}$-thymidine incorporation, ${ }^{3} \mathrm{H}$ leucine incorporation, TdR cell ${ }^{-1}$ and Leu cell-1 are temperature dependent. This is based on the following evidence. Substrate addition effects only occurred when the in situ temperature exceeded $20^{\circ} \mathrm{C}$. TdR $\mathrm{cell}^{-1}$ values for the first sampling point (i.e. before the addition of substrates) in the June and September experiments were about 2 to 10 times higher than those of the March experiment. This might be due to the difference in in situ temperature. In the June and September experiments, TdR cell-1 values for the first sampling point of the tidal creek samples were about 2 times those of the Bay samples and ${ }^{3} \mathrm{H}$-thymidine incorporation rates and $\mathrm{TdR}$ cell $^{-1}$ values of the tidal creek samples responded much faster than the Bay samples to the addition of substrate. These effects coincided with the higher in situ temperature $\left(>30^{\circ} \mathrm{C}\right)$ in the tidal creek. 


\section{Substrate-temperature interaction}

Pomeroy et al. (1991) and Wiebe et al. (1992, 1993) demonstrated that bacteria required higher concentrations of substrate for active growth at the annual minimum temperature. They suggested that both temperature and substrate effects should be considered in evaluating the limits to the microbial loop (and bacterial) activity. Kirchman et al. (1993) showed that in the subarctic Pacific, bacterial specific growth rates could be enhanced by either temperature increases or dissolved organic matter (DOM) additions. However, bacterial specific growth rates were affected faster by temperature increases than by DOM additions. They concluded that both temperature and substrate supply were important in controlling bacterial specific growth rate and that temperature cannot be considered as an independent controlling factor because increased specific growth rate must be based on the supply of substrate.

Our temperature-substrate interaction experiments indicated that after $24 \mathrm{~h}$, increasing the incubation temperature could still enhance $\mathrm{TdR}$ cell ${ }^{-1}$ equally in the control and substrate treatments. High substrate concentration did not enhance bacterial abundance, ${ }^{3} \mathrm{H}$-thymidine incorporation and $\mathrm{TdR}$ cell ${ }^{-1}$ during March 1992 experiments when in situ temperatures were low (i.e. $<5^{\circ} \mathrm{C}$ ). These results indicate that temperature is more effective in regulating $\mathrm{TdR}_{\mathrm{C}} \mathrm{cel}^{-1}$ than substrate when compared at the same time scale. The homogeneous pattern of slopes for $\ln \left(\mathrm{TdR}_{\mathrm{cell}}{ }^{-1}\right)$ and In (Leu cell $\left.{ }^{-1}\right)$ on temperature versus chlorophyll concentrations indicated that there was not a strong interaction between temperature and the coupling of bacterial growth with phytoplankton (Fig. 4A, B)

Substrate effects on bacterial growth seem to require more time for expression than temperature effects, which are expressed almost immediately. Kjeldgaard et al. (1958) showed that when cultures of Salmonella typhimurium were transferred to enriched medium (shift-up), DNA synthesis rates and cell division responded with a lay period of 20 to $70 \mathrm{~min}$. Interestingly, their results also showed that durnng the shift-up experiments, the lag period for DNA synthesis and cell division could be shortened $50 \%$ by increasing incubation temperature from 25 to $37^{\circ} \mathrm{C}$. Hollibaugh (1979) showed that DFAA uptake rates had a lag period of $60 \mathrm{~h}$ for response to DFAA enrichment, and that the lag period could be reduced from 240 to $48 \mathrm{~h}$ when temperature was increased from 3 to $25^{\circ} \mathrm{C}$. These support the hypothesis proposed above, suggesting that the substrate effects on bacterial growth are temperature dependent.

In estuarine and coastal ecosystems, substrate supply for bacterial growth can come from allochthonous and autochthonous inputs. By comparing bacterial biomass in lakes and the oceans, Simon et al. (1992) showed the intercepts of the correlations between bacterial and phytoplankton biomass were higher for lakes than oceans. They suggested that allochthonous substrate sources, in addition to phytoplankton production, support higher bacterial biomass in lakes. Findlay et al. (1992) estimated that in the Hudson Estuary, the amount of allochthonous carbon inputs necessary to support bacterial productivity were 3 to 6 times the net carbon fixation by phytoplankton. Riverine organic matter has been hypothesized to be important in supporting bacterial growth (Findlay et al. 1991, Chin-Leo \& Benner 1992). With so many possible substrate sources, it is not unreasonable to assume that in situ substrate supply in temperate estuaries will not limit bacterial growth during non-summer seasons and the results presented here confirm this hypothesis.

\section{CONCLUSIONS}

The growth of bacteria in the Chesapeake Bay ecosystem is primarily limited by temperature instead of substrate availability during non-summer seasons when temperature is $<20^{\circ} \mathrm{C}$. The temperature effect on estuarine bacterial specific growth rate is independent of habitat, season, in situ chlorophyll concentrations and substrate availability. The relative importance of temperature and substrates for bacterial growth may shift in different habitats or in different seasons (summer versus non-summer). The lack of substrate-temperature interaction and the dominance of temperature over substrate can only occur when substrate supply is not limiting the growth of bacteria When higher temperatures allow faster maximum bacterial growth rates, however, cells require greater rates of substrate supply and substrates could become limiting. This could be due to bacterial growth rates having a stronger temperature dependence than processes which supply substrates so the bacterial requirement for substrate exceeds the supply as temperature rises.

Acknowledgements. This research was supported by grants from the NOAA-University of Maryland Sea Grant, and the NSF Land-Margin Ecosystem Research Program. Support for F.-K.S. was provided by the Department of Education, Taiwan, ROC, Maryland Sea Grant, Horn Point Environmental Laboratory and the EPA Multiscale Experimental Ecosystem Research Center (HPEL MEERC). We thank S. Pike, J. Ludlam and C. Madden for cruise assistance, C. Carlson for discussions about the manuscript and D. Stoecker for commenting on the manuscript. Finally we thank the officers and crews of RV 'Cape Henlopen' and RV 'Cape Hatterass' for assistance during the field phase of this project. 


\section{LITERATURE CITED}

Autio, R. M. (1992). Temperature regulation of brackish water bacterioplankton. Hydrobiologia 37: 253-263

Bird, D. F. Kalff, J. (1984). Empirical relationships between bacterial abundance and chlorophyll concentration in fresh and marine waters. Can. J. Fish. Aquat. Sci. 41. $1015-1023$

Bjornsen, P. K., Riemann, B., Horsted, S. J., Nielsen, T G., Pock-Sten, J. (1988). Trophic interactions between heterotrophic nanoflagellates and bacterioplankton in manipulated seawater enclosures. Limnol. Oceanogr. 33: 409-420

Bolter, M. (1982). Submodels of a brackish water environment. I. Temperature and microbial activity. Ecol. Modelling 17: 311-318

Bott, T L. (1975). Bacterial growth rates and temperature optima in a stream with a fluctuating thermal regime. Limnol. Oceanogr. 20(2): 191-197

Chesbro, W., Arbige, M., Eifert, R. (1990). When nutrient limitation places bacteria in the domains of slow growth: metabolic, morphologic and cell cycle behavior. FEMS Microbiol. Ecol. 74: 103-120

Chin-Leo, G., Benner, R. (1992). Enhanced bacterioplankton production and respiration at intermediate salinities in the Mississippi River plume. Mar. Ecol. Prog. Ser. 87: 87-103

Chin-Leo, G., Kirchman, D. L. (1988). Estimating bacterial production in marine waters from the simultaneous incorporation of thymidine and leucine. Appl. environ. Microbiol. $54(8)$ : $1934-1939$

Coffin, R. B. (1989). Bacterial uptake of dissolved free and combined amino acids in estuarine waters. Limnol. Oceanogr. 34(3): 531-542

Cole, J. J. Findlay, S., Pace, M. L. (1988). Bacterial production in fresh and saltwater ecosystems: a cross-system overview. Mar. Ecol. Prog. Ser. 43: 1-10

Coveney, M. F., Wetzel, R. G. (1992). Effects of nutrients on specific growth rate of bacterioplankton in oligotrophic lake water culture Appl, environ. Microbiol. 58(1): $150-156$

Currie, D. J. (1990). Large-scale variability and interactions among phytoplankton, bacterioplankton, and phosphorus. Limnol. Oceanogr. 35(7): 1437-1455

Ducklow, H. W., Carlson, C. A. (1992). Oceanic bacterial production. In: Marshall, K. C. (ed.) Advances in microbial ecology, Vol. 12. Plenum Press, New York, p. 113-181

Ducklow, H. W., Shiah, F. (1993). Bacterial production in estuaries. In: Ford, T. (ed.) Aquatic microbiology: an ecological approach. Vol. 11. Blackwell Scientific Publ., New York, p. $261-288$

Edwards, A. L. (1985). Multiple regression and analysis of variance and covariance. Freeman \& Co., New York

Findlay, S., Pace, M. L., Lints, D., Cole, J. J. (1991). Weak coupling of bacterial and algal production in a heterotrophic ecosystem: the Hudson River estuary. Limnol. Oceanogr. 36(2): $268-278$

Findlay, S., Pace, M. L., Lints, D., Howe, K. (1992). Bacterial metabolism of organic carbon in the tidal freshwater Hudson Estuary. Mar. Ecol. Prog. Ser. 89: 147-153

Fuhrman, J. A., Azam, F. (1980). Bacterioplankton secondary production estimates for coastal waters of British Columbia, Antarctica, and California. Appl. environ. Microbiol. 39(6): 1085-1095

Fuhrman, J. A., Azam, F. (1982). Thymidine incorporation as a measurement of heterotrophic bacterioplankton production in marine surface waters: Evaluation and field results. Mar. Biol. 66: 109-120
Hobbie, J. E., Daley, R. J., Jasper, S. (1977). Use of nuclepore filters for counting bacteria by fluorescence microscopy. A.ppl. environ. Microbiol. 33(5): 1225-1228

Hoch, M, Kirchman, D. L. (1993). Seasonal and inter-annual variablity in bacterial production and biomass in a temperate estuary. Mar. Ecol. Prog. Ser. 98: 283-295

Hollibaugh, J. T. (1979). Metabolic adaptation in natural bacterial populations supplemented with selected amino acids. Estuar. coast. mar. Sci. 9: 215-230

Iriberri, J., Undurraga, A., Muela, A., Egea, L. (1985). Heterotrophic bacterial activity in coastal waters: functional relationship of temperature and phytoplankton population. Ecol. Modelling 28: 113-120

Kirchman, D., K'nees, E., Hodson, R. (1985). Leucine incorporation and its potential as a measure of protein synthesis by bacteria in natural systems. Appl. environ. Microbiol. 49(3): 599-607

Kirchman, L. D., Keil, R. G., Simon, M., Weischmeyer, N. A. (1993). Biomass and production of heterotrophic bacterioplankton in the oceanic subarctic Pacific. Deep Sea Res. 40(5): $967-988$

Kjeldgaard, N. O., Maaløe, O., Schaechter, M. (1958). The transition between different physiological states during balanced growth of Salmonella typhimurium. J. gen. Microbiol. 19: 607-616

Lancelot, C., Billen, G. (1984). Activity of heterotrophic bacteria and its coupling to primary production during the spring phytoplankton bloom in the southern bight of the North Sea. Limnol. Oceanogr. 26(4): 721-730

Lee, S., Fuhrman, J. A. (1990). DNA hybridization to compare species compositions of natural bacterioplankton assemblages. Appl. environ. Microbiol. 56: 739-746

Li, W. K. W., Dickie, P. M. (1987). Temperature characteristics of photosynthetic and heterotrophic activities: seasonal variations in temperate microbial plankton. Appl. environ. Microbiol. 53(10): 2282-2295

Li, W. K. W., Morris, I. (1982). Temperature adaptation in Phaeodactylum tricornutum Bohlin: photosynthetic rate compensation and capacity. J. exp. mar. Biol. Ecol. 58: $135-150$

Lovell, C. R., Konopka, A. (1985). The effects of temperature on bacterial production in a dimictic eutrophic lake. FEMS Microbiol. Ecol. 31: 135-140

Maita, Y., Yanda, M. (1978). Particulate protein in coastal waters, with special reference to seasonal variation. Mar. Biol. 44: 329-326

Malone, T. C., Ducklow, H. W., Peele, E. R., Pike, S. E. (1991). Picoplankton carbon flux in Chesapeake Bay. Mar. Ecol. Prog. Ser. 78: 11-22

Painchaud, J., Therriault, J. C. (1989). Relationships between bacteria, phytoplankton and particulate organic carbon in the upper St. Lawrence Estuary. Mar Ecol. Prog. Ser. 56: $301-311$

Pomeroy, L. R., Wiebe, W. J., Deibel, D, Thompson, R. J., Rowe, G. T., Pakulski, J. D. (1991). Bacterial responses to temperature and substrate concentration during the Newfoundland and spring bloom. Mar. Ecol. Prog. Ser. 75: 143-159

Quinlan, A. V. (1981). Thermo-chemical optimization of ecological process. In: Mitsch, W. J., Bosserman, R. W. Klopatek, J. M. (eds.) Energy and ecological modeling Elsevier, Amsterdam, p. 635-640

Schaechter, M., Maaløe, O., Kjeldgaard, N. O. (1958). Dependency on medium and temperature of cell size and chemical composition during balanced growth of Salmonella typhimurium. J, gen. Microbiol. 19: 592-606

Servais, P., Billen, G. (1989). Impact of a nuclear power plant on primary production and bacterial heterotrophic activity 
in the River Meuse at Tihange (Belgium). Hydrobiologia 114(3): 415-429

Shiah, F.-K. (1993). Multi-scale variability of bacterioplankton abundance, production and growth rate in the temperate estuarine ecosystems. Ph.D. thesis, University of Maryland, Cambridge

Simon, M., Cho, B. C., Azam, F. (1992). Significance of bacterial biomass in lakes and the ocean: comparison to phytoplankton biomass and biogeochemical implications. Mar. Ecol. Prog. Ser. 86: 103-110

Toolan, T., Wehr, J. D. Findlay, S. (1991). Inorganic phosphorus stimulation of bacterioplankton production in a mesoeutrophic lake. Appl. environ. Microbiol. 57(7): 2074-2078

Topiwala, H., Sinclair, C. G. (1971). Temperature relationship in continuous culture. Biotech. Bioeng. 13: 795-813

Upton, A. C., Nedwell, D. B., Wynn-Williams, D. D. (1990). The selection of microbial communities by constant or fluctuating temperatures. FEMS Microb. Ecol. 74: $243-252$

This article was presented by S. Y. Newell, Sapelo Island, Georgia, USA
White, P. A., Kalff, J., Rasmussen, J. B., Gasol, J. M. (1991). The effects of temperature and algal biomass on bacterial production and specific growth rate in freshwater and marine habitats. Microb. Ecol. 21: 99-118

Wiebe, W. J., Sheldon, W. M. Jr, Pomeroy, P. M. (1992). Bacterial growth in the cold: evidence for an enhanced substrate requirement. Appl. environ. Microbiol. 58: $359-364$

Wiebe, W. J., Sheldon, W. M. Jr, Pomeroy, P. M. (1993). Evidence for an enhanced substrate requirement by marine mesophilic bacterial isolates at minimal growth temperatures. Microb. Ecol. 25: 151-159

Wilkinson, L., Hill, M., Miceli, S., Howe, P., Vang, E. (1992). SYSTAT for the Macintosh, version 5.2. SYSTAT Inc. Evanston, IL

Witzel, K. P. (1980). Temperature compensation of $\left[\mathrm{U}-{ }^{14} \mathrm{C}\right]$ glucose incorporation by microbial communities in a river with a fluctuating thermal regime. Appl. environ. Microbiol. 39(4): $790-796$

Manuscript first received: June 8, 1993

Revised version accepted: September 20,1993 